\title{
MI6: British Secret Intelligence Service Operations 1909-1945. By Nigel West. South Yorkshire, UK: Frontline Books, 2019.
}

Ed J. Hagerty

American Public University System

Follow this and additional works at: https://digitalcommons.usf.edu/jss

pp. $149-152$

\section{Recommended Citation}

Hagerty, Ed J.. "MI6: British Secret Intelligence Service Operations 1909-1945. By Nigel West. South Yorkshire, UK: Frontline Books, 2019.." Journal of Strategic Security 13, no. 3 (2020) : 149-152.

DOI: https://doi.org/10.5038/1944-0472.13.3.1874

Available at: https://digitalcommons.usf.edu/jss/vol13/iss3/7

This Book Review is brought to you for free and open access by the Open Access Journals at Digital Commons @ University of South Florida. It has been accepted for inclusion in Journal of Strategic Security by an authorized editor of Digital Commons @ University of South Florida. For more information, please contact digitalcommons@usf.edu. 
MI6: British Secret Intelligence Service Operations 1909-1945. By Nigel West. South Yorkshire, UK: Frontline Books, 2019. 


\section{MI6: British Secret Intelligence Service Operations 1909-1945. By Nigel West. South Yorkshire, UK: Frontline Books, 2019. ISBN:9781526755742 Charts. Photos. Notes. Index.. Pp. xxii, 290. \$34.95.}

First released in the UK in 1983 , this handsome reprint is a welcome addition that once again provides easy access to West's detailed look at the origins of Britain's Secret Intelligence Service (SIS) known as MI6. West has been a highly respected though sometimes controversial figure in the Intelligence field for many years. One might even say the controversies begin with the fact that there is no "Nigel West." Instead, it is the pen name of Britain's former Conservative Party Member of Parliament Rupert Allason. Nonetheless, under his nom de plume West has authored an incredible selection of historical books on intelligence agencies and operations over the last forty years, and those works have marked him as a tenacious researcher and noted expert in the field.

West's MI6 is a useful companion to his previously published work on MI5. Together the books give readers insight not only into the administrative processes that led to the creation of those agencies, but also to MI6's many failures and the inter-agency conflicts, along with the less frequent triumphs, that marked the early years. Less apparent in the MI6 volume is a full discussion of actual operations. Details are often necessarily sacrificed in the interest of focusing more how cases affected the growth and development of the agency. Selected influential cases do receive more complete examination. This is not a significant flaw; other authors have detailed a number of those cases in books more specifically dedicated to operational activities, and West himself has explored several of them in his own succeeding works.

MI6 is divided into two main parts. The first covers the period 1903-1940, and the second covers from 1940-1945. Part one includes chapters on the earliest years of the service, which was thrust into the First World War within a few years of its creation after focusing almost exclusively on Russia, not Germany. During that conflict SIS was often sidelined or overshadowed by the older and more maturely competent Naval Intelligence Division. Chapters focused on each of the service's leaders: Mansfield Cumming, Hugh Sinclair, and Stewart Menzies inform readers of the service's growth and struggles as well as the roles those leaders 
played in shaping the focus and direction of the operations that would eventually prove the worth of SIS and bring it into its own. One early mistake West suggests, however, might have been the use of Passport Control Offices (PCO) as the primary cover for SIS operatives. This served to increase tensions between SIS and the Foreign Office and led to a host of other issues. Once it became known, for example, that Passport Control was a cover for intelligence officers-a reality the Germans figured out pretty quickly-it became an easy matter to identify those intelligence officers simply by walking into the office and applying for a visa. In fact, visa applications sometimes took up such a substantial portion of the PCO's time that intelligence work had to take a back seat. This became a particular problem when an increasing number of applications were made by those seeking to flee the rising threat of Nazi rule in Europe.

In addition to the PCOs, Sinclair had also established a totally separate network of agents operating under commercial cover known simply as Z. One of the $Z$ agents, in the midst of Menzies' later efforts to combine the two networks, was involved in SIS' greatest pre-war misstep in the fall of 1939. The so-called Venlo incident involved two senior SIS officers in The Hague who thought they had arranged with much clandestine effort and negotiation to meet a highly placed, anti-Nazi Wehrmacht general whom they intended to spirit to London for secret talks about a possible coup and the arrest of Hitler. Instead the two agents found themselves suddenly kidnapped near Venlo on the German-Dutch border in what turned out to be an elaborate Nazi Security Service scheme that completely compromised SIS's already shaky order of battle. An appendix in the book provides the actual Abwehr synopsis of debriefs of the two kidnapped agents and shows how fully the organization was compromised. Such incidents along with the generally poor quality of intelligence provided by SIS over the years weakened its reputation in Whitehall, so much so that when the first ULTRA decrypts were later circulated they were largely ignored because of the distrust resulting from the accumulated disappointment with SIS's previous information. Fortunately for MI6, the decryption work at Bletchley soon proved its value, and West speculates that had those efforts not been so critical to the war effort it's possible "neither Menzies nor his organization could have survived" (263). Instead, by the end of the Second World War MI6 had ascended to its zenith. Kim Philby and his associates in the Cambridge Five would bring the agency down several pegs once more after that. 
Part two is mostly broken into chapters addressing operations in various locations throughout Europe and the Middle East. It is about a third longer than part one even though it covers only the five years of war, during which SIS was largely compelled to obtain much of its information in exchange for the support it provided to networks run by governments exiled from the Continent. SIS's structure was skeletal after Hitler's troops had marched over most of Europe, and though its training and support for the exiled governments' networks was important, SIGINT eventually would constitute its saving grace. Unlike World War I, where the Germans had severely restricted their use of battlefield wireless communications, the Enigma machines of World War II provided the Nazis with the confidence to greatly increase radio traffic. It proved at first to be an embarrassment of riches to SIS. Staff levels, equipment, and processes were too immature to handle the influx of raw intelligence, and that flaw took time to address effectively. In addition, MI6's credibility issues and its lackluster performance in comparison to MI5's successes meant the war's early years were still a struggle.

If SIS operations seemed apprentice-like at times, failures were often compounded by the brave yet frequently naïve actions of the stay-behind intelligence networks on the Continent. Many were filled with volunteers wholly untrained in intelligence operations, and the networks were sometimes riddled with informants. One illustrative example is that of the French INTERALLIE network led by a Polish operative codenamed VALENTIN, which proved highly successful at first. Eventually the network was dismantled when a disgruntled cipher clerk and one of INTERALLIE's sector leaders betrayed the organization. Within three days the network's entire staff had been arrested. The cipher clerk agreed to inform SIS that VALENTIN had been arrested and that she would be taking over the network herself. VICTOIRE thus replaced VALENTIN, and she continued to supply info to SIS using the network's radio sets now controlled by the Abwehr. As a result, SIS even connected VICTOIRE with operatives from Britain's Special Operations Executive (SOE). The result was the immediate interception of two SOE agents landed on the coast. Once the duplicity was discovered SIS had only to benefit from the hard lessons learned about lax security procedures and insufficient compartmentalization, the negative results of which were only compounded by innocently bringing SOE into the mess. 
The record was not all one of failure however, and among other successes SIS neutralized NAZI efforts to establish two infra-red detectors placed on opposite coasts near the Straits of Gibraltar that would have seriously hindered Allied passage through that area and jeopardized the landings in North Africa. The detector system on the coast near Tangiers was blown into the sea by SIS agents, which caused the then useless matching system in Spain to be abandoned.

One particularly interesting chapter is devoted to the role of the American Office of Strategic Services (OSS). MI6 had enough problems of its own, but those were compounded by the sudden insertion of the cousins' amateurish efforts into the mix. Disagreements over operational methods or whom to employ as operatives even led to instances of SIS obstructing OSS operations. An OSS focus on short-term gains unfortunately led the agency to rely on and support a number of leftist organizations, which ended up being politically well placed and able to influence Allied policies in the post-war era.

One complaint about the book is the paucity of notes (fifteen in all) and the absence of a bibliography. That flaw certainly limits the book's usefulness to researchers, but for a general overview of the founding of MI6 and a glimpse at some select operations, it's perfectly adequate and definitely worth reading.

Edward J. Hagerty, American Public University System 